\title{
PENGARUH STRATEGI PEMBELAJARAN DAN KEMAMPUAN BERPIKIR LOGIS TERHADAP HASIL BELAJAR BIOLOGI
}

\author{
Anis Rabwiningsih ${ }^{1}$ dan Abdul Muin Sibuea ${ }^{2}$ \\ MAN 1 Kabanjahe, Karo, Sumatera Utaral dan Universitas Negeri Medan ${ }^{2}$ \\ anisrabwiningsih@gmail.com ${ }^{l}$ dan muin_sibuea@yahoo.com ${ }^{2}$
}

\begin{abstract}
Absrak: Penelitian ini bertujuan untuk: (1) mengetahui apakah hasil belajar biologi siswa yang diajar dengan strategi pembelajaran inkuiri lebih tinggi daripada hasil belajar biologi siswa yang diajar dengan pembelajaran advanced organizer, (2) mengetahui apakah hasil belajar siswa yang memiliki kemampuan berpikir logis tinggi daripada siswa yang memiliki kemampuan berpikir logis rendah; dan (3) mengetahui apakah terdapat interaksi antara strategi pembelajaran dan kemampuan berpikir logis siswa dalam mempengaruhi hasil belajar siswa. Hasil penelitian ini menunjukkan bahwa: (1) rata-rata hasil belajar siswa yang diajar dengan strategi pembelajaran inkuiri lebih tinggi dibandingkan dengan strategi pembelajaran advanced organizer; (2) rata-rata hasil belajar siswa dengan kecenderungan tingkat kemampuan berpikir logis tinggi lebih tinggi dibandingkan dengan kemampuan berpikir logis rendah; dan (3) terdapat interaksi antara perbedaan pengaruh strategi pembelajaran dan kemampuan berpikir logis.
\end{abstract}

Kata Kunci: strategi pembelajaran, kemampuan berpikir logis, hasil belajar biologi

Abstract: This study aims to: (1) determine whether the results of studying biology students taught by instructional strategy of inquiry is higher than the results of studying biology students who are taught by learning advanced organizer, (2) determine whether the learning outcomes of students who have the ability to think logically high than students who have the ability to think logically low; and (3) determine whether there is an interaction between learning strategy and logical thinking ability of students in influencing student learning outcomes. The results showed that: (1) the average student learning outcomes are taught by inquiry learning strategies more than in the advanced learning strategies organizer; (2) the average student learning outcomes with a tendency to high levels of logical thinking ability is higher than the low logical thinking ability; and (3) there is an interaction between the different effects of learning strategies and the ability to think logically.

Keywords: learning strategies, logical thinking ability, learning outcomes biology

\section{PENDAHULUAN}

Untuk menyahuti amanat di atas, maka perbaikan dan peningkatan mutu pendidikan yang dilakukan pemerintah melalui berbagai kebijakan yang diambil misalnya penyempurnaan kurikulum, sertifikasi pendidik dan tenaga kependidikan, bantuan operasional sekolah (BOS) dan pemenuhan kebutuhan sarana dan prasarana yang berkaitan langsung dengan pembelajaran.

Namun demikian masih terdapat hambatan-hambatan serta kekurangankekurangan. Terdapat banyak faktor yang menyebabkan rendahnya hasil belajar yang diperoleh siswa dalam pembelajaran, antara lain sebagaimana yang diungkapan oleh Hamalik (2004) bahwa secara operasional terdapat lima variabel utama yang berperan dalam mempengaruhi hasil belajar, yaitu: (1) tujuan pembelajaran, (2) materi pelajaran, (3) metode dan teknik mengajar, (4) guru dan (5) logistik. Kelima variabel tersebut memiliki ketergantungan satu sama lain dan tidak dapat berdiri sendiri dalam memberhasilkan pembelajaran.

Selanjutnya berkaitan dengan belum berhasilnya pembelajaran dijelaskan Sibuea dan Amin (2005) sebagai faktor penyebabnya adalah pelaksanaan pembelajaran yang dilakukan di sekolah masih bersifat konvensional. Pembelajaran masih berorientasi pada "teacher centered", yaitu guru masih menekankan pada peran sebagai penyampai materi pelajaran di mana strategi pembelajaran 
yang digunakan adalah strategi konvensional yang merupakan salah satu strategi pembelajaran yang cukup populer dipakai oleh guru dan cukup efektif untuk menyampaikan materi pelajaran secara tuntas.

Hal senada dijelaskan oleh Djuwita (2011) dalam pembelajaran Biologi, oleh siswa masih dianggap sebagai pelajaran hafalan. Kecenderungan siswa menghafal nateri pelajaran yang telah disampaikan guru mengakibatkan materi pelajaran tersebut mudah dilupakan. Selanjutnya beberapa temuan penelitian yang diekspos dalam jurnal Biologi Unimed yaitu Sartika dan Hasruddin (2010) menemukan beberapa masalah dalam pembelajaran Biologi adalah rendahnya minat dan motivasi siswa dalam pembelajaran Biologi, hal ini tentunya menyulitkan siswa memahami dan mengingat dengan baik materi pelajaran Biologi dalam waktu jangka panjang.

Fauziah (2010) menemukan bahwa pemahaman guru Biologi di kota Medan menunjukkan pada tataran konsep-konsep teoritis sehingga kondisi tersebut tentunya mempengaruhi perolehan hasil belajar Biologi siswa. Padahal diketahui bahwa materi pembelajaran Biologi meliputi objek kajian terdiri atas objek material (materi yang dibahas) dan objek formal (cara pandang). Objek formal biologi adalah makhluk hidup dan makhluk yang pernah hidup (fosil). Adapun objek formalnya berkaitan dengan struktur, fungsi, dan interaksi makhluk hidup.

Berkaitan dengan rendahnya perolehan hasil belajar dijelaskan Syah (2004) menjelaskan faktor yang mempengaruhinya yaitu: (1) faktor internal siswa, (2) faktor eksternal siswa, dan (3) faktor pendekatan belajar. Faktor pendekatan belajar merupakan salah satu faktor yang akan membuat siswa merasa tertarik untuk belajar melalui penyampaian guru. Guru yang mampu menerapkan berbagai pendekatan belajar cenderung akan mampu mengelola kelas dengan baik sehingga penyajian pembelajaran tidak membosankan. Lebih lanjut Syah (2004) menjelaskan faktor internal siswa yang utama yang mempengaruhi keberhasilan siswa dalam belajar antara lain minat, kesehatan, motivasi, perhatian, ketenangan jiwa, kegairahan, kebugaran jasmani, dan kepekaan alat-alat indera dalam belajar, serta faktor lingkungan belajar, interaksi dengan teman sebangku, interaksi siswa dengan gurunya. Berdasarkan uraian tersebut di atas jelas bahwa terdapat berbagai faktor yang mempengaruhi keberhasilan siswa dalam belajar. Dalam mengajar guru harus memperhatikan karakteristik siswa seiring dengan peningkatan kualitas pembelajarannya.

Di samping pemilihan strategi pembelajaran yang tepat, perolehan hasil belajar Biologi, juga dipengaruhi oleh karakteristik siswa itu sendiri yaitu kemampuan berpikir logis. Dalam hal ini, Santrock (2008) menjelaskan berpikir adalah memanipulasi atau mengelola dan mentransformasi informasi dalam memori. Dengan demikian berpikir logis yakni kemampuan siswa dalam menerapkan metode berpikir logis untuk menemukan jawaban.

Hergenhahn dan Olson (2008) menjelaskan bahwa belajar adalah perubahan prilaku atau potensi prilaku yang relatif permanen dan berasal dari pengalaman dan tidak bisa dinisbahkan ke temporary body state (keadaan tubuh temporer) seperti keadaan yang disebabkan oleh sakit, keletihan atau obatobatan. Selanjutnya Hergenhahn dan Olson (2008) menjelaskan lima hal yang harus diperhatikan berkaitan dengan belajar yaitu: (1) belajar diukur berdasarkan perubahan dalam prilaku, (2) perubahan prilaku relatif permanen, (3) perubahan prilaku itu tidak selalu terjadi secara langsung setelah proses belajar selesai, (4) perubahan prilaku berasal dari pengalaman atau latihan, dan (5) pengalaman atau latihan harus diperkuat

Woolfolk (2009) menjelaskan belajar adalah suatu proses perubahan permanen pada pengetahuan atau prilaku yang diakibatkan oleh pengalaman. Selanjutnya dijelaskan Woolfolk bahwa untuk syarat yang harus dipenuhi dalam definisi belajar tersebut yaitu: (1) perubahan itu harus diwujudkan oleh pengalaman yaitu interaksi individu dengan lingkungannya, (2) perubahan itu tidak sebabkan oleh kematangan seperti tubuh menjadi lebih tinggi atau rambut yang mulai berubah, dan (3) perubahan akibat sakit, kelelahan atau kelaparan bukan termasuk definisi belajar tersebut.

Hal senada diungkapkan Snelbecker (1974) mengatakan, bahwa ciri-ciri tingkah laku yang diperoleh dari belajar adalah (a) terbentuknya tingkah laku berupa kemampuan aktual maupun potensial, (b) kemampuan itu berlaku dalam waktu yang relatif lama, dan (c) kemampuan itu diperoleh melalui usaha. Mulyati (2005) menjelaskan bahwa belajar adalah merupakan suatu usaha sadar individu 
untuk mencapai tujuan peningkatan diri atau perubahan diri melalui latihan-latihan dan pengulangan-pengulangan dan perubahan yang terjadi bukan karena peristiwa kebetulan semata.

Romizowski (1981) menyatakan bahwa hasil belajar diperoleh dalam bentuk yaitu: (1) pengetahuan, dan (2) keterampilan. Pengetahuan dikelompokkan kepada empat kategori, yaitu fakta, konsep, prinsip dan prosedur. Fakta merupakan pengetahuan tentang obyek nyata yang merupakan asosiasi dari kenyataan-kenyataan dan informasi verbal dari suatu obyek, peristiwa atau manusia. Konsep merupakan pengetahuan tentang seperangkat obyek konkrit atau definisi. Prinsip adalah merupakan pernyataan mengenai hubungan dua konsep atau lebih, hubungan itu bisa bersifat kausalitas, korelasi atau aksiomatis. Prosedur merupakan pengetahuan tentang tindakan demi tindakan yang bersifat linier dalam mencapai suatu tujuan.

$$
\text { Gagné dan Briggs (1979) }
$$

mengemukakan, hasil belajar dapat dikelompokkan ke dalam lima kategori, yaitu keterampilan intelektual, strategi kognitif, informasi verbal, kemampuan motorik dan sikap. Howard Kingsley dalam Sudjana (2002) menjelaskan tiga macam hasil belajar yakni: (1) keterampilan dan kebiasaan, (2) pengetahuan dan pengertian dan (3) sikap dan cita-cita dapat diisi dengan bahan yang ditetapkan dalam kurikulum sekolah. Kemp (1994) menjelaskan hasil belajar akan terlihat dengan adanya tingkah laku baru pada tingkat kemampuan berpikir atau kemampuan jasmaniah.

$$
\text { Merril dan Twitchell }
$$

mengelompokkan hasil belajar ke dalam dua dimensi yaitu tingkat kinerja (performance) dan tipe isi (content matrix). Dimensi tingkat kinerja terdiri dari mengingat, menggunakan, dan menemukan. Mengingat berkaitan dengan kinerja yang menuntut siswa melakukan penelusuran struktur ingatan agar dapat mengungkapkan kembali konstruk-konstruk yang telah disimpan di dalamnya. Menggunakan berkaitan dengan kinerja yang menuntut siswa menerapkan suatu abstraksi pada kasus-kasus khusus. Menemukan berkaitan dengan unjuk kerja yang menuntut siswa menemukan atau mengembangkan abstraksi baru.

Suparman (2001) mendefinisikan strategi pembelajaran sebagai perpaduan dari (1) urutan kegiatan instruksional, (2) cara pengorganisasian materi pengajaran dan siswa, (3) peralatan dan bahan dan (4) waktu yang digunakan dalam proses pembelajaran. Kedua definisi yang dikemukakan para ahli di atas pada prinsipnya lebih menekankan pada aspek komponen dan prosedur pengajaran.

Romizowski (1981) berpendapat bahwa strategi pembelajaran merupakan suatu pendekatan menyeluruh yang dapat dibedakan menjadi dua strategi dasar, yaitu ekspositori dan inquiri. Kedua strategi ini dapat dipandang sebagai dua ujung yang sejalan dalam suatu kontinum strategi, hal ini erat sekali kaitannya dengan pendekatan deduktif dimana strategi ini dimulai dengan penyajian informasi mengenai prinsip atau kaidah kemudian diikuti dengan tes penguasaan, penerapan dalam bentuk contoh dan penerapan pada situasi tertentu. Sedangkan strategi inquiri/diskoveri didasarkan pada teori belajar pengalaman yang disebut juga teori belajar pengalaman.

Merill (1981) mengklasifikasikan strategi pembelajaran atas tiga dasar (1) tujuan pengajaran meliputi sepuluh kombinasi antara jenis materi dan tingkah laku yang diharapkan, (2) cara mempresentasikan materi yaitu dari tingkat yang khusus ke tingkat yang umum atau sebaliknya dari tingkat yang umum ke tingkat khusus, (3) bentuk respon siswa dibedakan atas strategi ekspositori dan inkuri.

Romizowski (1981) menyatakan bahwa setiap strategi pembelajaran yang dikembangkan selalu mencerminkan posisi teoretis yang dianut tentang bagaimana seharusnya pembelajaran itu dilaksanakan. Oleh karena itu guru sebagai penyelenggara kegiatan pembelajaran dituntut mampu mengupayakan terjadinya interaksi siswa dengan komponen sistem pembelajaran yang lain secara optimal.

Wena (2009) menjelaskan strategi pembelajaran berarti cara dan seni untuk menggunakan semua sumber belajar dalam upaya membelajarkan siswa. Sebagai suatu cara, strategi dikembangkan dengan kaidahkaidah tertentu sehingga membentuk suatu bidang pengetahuan, strategi pembelajaran dapat dipelajari dan kemudian diaplikasikan dalam kegiatan pembelajaran. Sebagai suatu seni, strategi pembelajaran kadang-kadang secara immplisit dimiliki seseorang tanpa pernah belajar secara formal entang ilmu strategi pembelajaran.

$\begin{array}{ccc}\text { Sanjaya (2007) menjelaskan } & \text { prinsip- } \\ \text { prinsip umum penggunaan strategi }\end{array}$ 
pembelajaran yaitu: (1) berorientasi pada tujuan, yaitu dalam pembelajaran tujuan merupakan komponen yang utama, keberhasilan suatu strategi tergantung pada tercapainya tujuan, (2) aktivitas, strategi pembelajaran harus dapat mendorong aktivitas siswa, (3) individualitas, strategi pembelajaran pada hakikatnya ingin mencapai perubahan prilaku setiap siswa dan (4) integritas, strategi pembelajaran harus dapat mengembangkan seluruh aspek kepribadian siswa secara terintegrasi.

Arends (2008) menjelaskan pembelajaran inkuiri adalah pembelajaran yang penekanannya untuk membantu siswa menyelidiki sendiri dan mengembangkan berbagai keterampilan seperti bertanya dan menarik kesimpulan dari data. Selanjutnya Jacobsen, Eggen dan Kauchak (2009) menjelaskan pembelajaran inkuiri merupakan sebuah proses dalam menjawab pertanyaanpertanyaan dan memecahkan masalah-masalah berdasarkan pada pengujian logis atas faktafakta dan observasi-observasi.

Poedjiadi (2005) menjelaskan bahwa inkuiri merupakan istilah serapan dari bahasa Inggris yaitu "inquiry" yang berarti penyelidikan atau penelitian. Sedangkan teori belajar yang mendasari strategi pembelajaran inkuiri adalah teori belajar konstruktivisme. Menurut teori belajar konstruktivisme, pengetahuan akan bermakna manakala dicari dan ditemukan sendiri oleh peserta didik, oleh karena itu tugas tenaga pengajar adalah mendorong peserta didik untuk mengembangkan pengetahuan dengan memfasilitasi kebutuhan belajar peserta didik.

Joyce, Weil dan Calhoun (2009) menjelaskan pembelajaran inkuiri dirancang untuk membawa secara langsung ke dalam proses logis melalui latihan-latihan yang dapat memadatkan proses logis tersebut ke dalam periode waktu yang singkat. Pembelajaran inkuiri tersebut akan meningkatkan pemahaman ilmu pengetahuan, produktivitas dalam berpikir kreatif dan keterampilan-keterampilan dalam memperoleh dan menganalisis informasi.

Jacobsen, Eggen dan Kauchak (2009) menjelaskan bahwa pembelajaran inkuiri dimulai dengan memberi siswa masalahmasalah yang berhubungan dengan konten yang nantinya menjadi fokus untuk aktivitas-aktivitas penelitian kelas. Dalam menyelesaikan masalah siswa menghasilkan hipotesis atau solusi tentatif untuk masalah tersebut, mengumpulkan data yang relevan dengan hipotesis yang telah dibuat dan mengevaluasi data tersebut untuk sampai kepada kesimpulan.

Lebih lanjut dijelaskan Jacobsen, Eggen dan Kauchak (2009) menjelaskan urgensi penerapan pembelajaran inkuiri adalah: (1) melalui pembelajaran inkuiri, guru memberikan dapat mengajarkan keterampilan investigatif dan sistematis kepada siswa, (2) melalui pembelajaran inkuiri memberikan pengalaman kepada siswa untuk mengaplikasikan pengetahuannya dengan aspek-aspek kehidupan lainnya, dan (3) melalui pembelajaran inkuiri siswa secara aktif terlibat dalam tiap tahap pembelajaran.

Sanjaya (2007) mendefinisikan strategi pembelajaran inkuiri adalah rangkaian kegiatan pembelajaran yang menekankan pada proses berpikir secara kritis dan analitis untuk mencari dan menemukan sendiri jawaban dari suatu masalah yang dipertanyakan. Strategi pembelajaran inkuiri berangkat dari asumsi bahwa sejak manusia lahir ke dunia, manusia memiliki dorongan untuk menemukan sendiri pengetahuannya. Rasa ingin tahu tentang keadaan alam di sekelilingnya merupakan kodrat manusia sejak ia lahir. Hamalik (2004) menyatakan strategi pembelajaran inkuiri adalah suatu strategi yang berpusat pada siswa di mana kelompok siswa melakukan penyelidikan dan penelitian ke dalam suatu isu atau mencari jawaban-jawaban terhadap isi pertanyaan melalui suatu prosedur yang digariskan secara jelas dan struktural kelompok.

Selanjutnya Gulo (2008) menjelaskan strategi pembelajaran inkuiri adalah rangkaian kegiatan belajar yang melibatkan secara maksimal seluruh kemampuan siswa untuk mencari dan menyelidiki secara sistematis, kritis dan logis, analitis, sehingga siswa dapat merumuskan sendiri penemuannya dengan penuh percaya diri. Oleh karena itu sasaran utama pembelajaran strategi inkuiri dijelaskan oleh Gulo (2008) yaitu: (1) keterlibatan siswa secara maksimal dalam proses kegiatan belajar. Kegiatan belajar di sini adalah kegiatan mental intelektual dan sosial emosional, (2) keterarahan kegiatan secara logis dan sistematis pada tujuan pembelajaran, dan (3) mengembangkan sikap percaya diri sendiri pada diri siswa tentang apa yang telah ditemukan dalam proses inkuiri.

Joyce, Weil dan Calhoun (2009) menjelaskan bahwa dalam pembelajaran inkuiri peran dan tugas guru adalah: (1) menyakinkan 
bahwa pertanyaan-pertanyaan diutarakan dengan baik sehingga pertanyaan tersebut dapat dijawab dengan ya atau tidak dan subtansi pertanyaan itu tidak mengharuskan guru melakukan penelitian, (2) meminta siswa untuk mengutarakan kembali pertanyaan yang kurang baik, (3) menegaskan dan menunjukkan poinpoin yang tidak disahkan, (4) menggunakan bahasa proses penelitian dan mengajak siswa melakukan pengujian, (5) mencoba menyediakan lingkungan intelektual yang bebas dengan tidak menilai teori-teori siswa secara keras, (6) mendesak siswa untuk membuat pernyataan-pernyataan teori yang lebih jelas dan menyediakan dukungan dalam menggeneralisasi teori, dan (7) mendorong interaksi antara siswa.

Suyanti (2008) menjelaskan bahwa strategi pembelajaran inkuiri didukung oleh empat karakteristik utama siswa yaitu: (1) secara intuitif siswa selalu ingin tahu, (2) di dalam percakapan siswa selalu ingin bicara dan mengkomunikasikan idenya, (3) dalam membangun (konstruksi) siswa selalu ingin membuat sesuatu, dan (4) siswa ingin mengekspresikan kemampuannya. Selanjutnya Suyanti (2008) menjelaskan prinsip yang terdapat dalam penerapan strategi pembelajaran inkuiri yaitu: (1) berorientasi pada pengembangan intelektual, dalam hal ini pengembangan kemampuan berpikir dan berorientasi pada proses belajar, (2) prinsip interaksi, dalam hal ini proses pembelajaran merupakan interaksi antara siswa dengan guru, (3) prinsip bertanya, dalam hal ini guru berperan sebagai penanya karena kemampuan siswa untuk bertanya pada dasarnya sudah merupakan bagian dari proses berpikir, (4) prinsip belajar untuk berpikir, dalam hal ini proses mengembangkan potensi seluruh otak secara maksimal, dan (5) prinsip keterbukaan, dalam hal ini siswa diberikan kebebasan untuk mencoba sesuatu sesuai dengan perkembangan kemampuan logika dan nalarnya..

Sanjaya (2007) menjelaskan bahwa ciri utama strategi pembelajaran inkuiri yaitu: (1) strategi pembelajaran inkuiri menekankan kepada aktivitas siswa secara maksimal untuk mencari dan menemukan, artinya strategi pembelajaran inkuiri menempatkan siswa sebagai subjek belajar, (2) seluruh aktivitas yang dilakukan siswa diarahkan untuk mencari dan menemukan jawaban sendiri dari sesuatu yang dipertanyakan, sehingga diharapkan dapat menumbuhkan sikap percaya diri (self belief), dan (3) tujuan dari penggunaan strategi pembelajaran inkuiri adalah mengembangkan kemampuan berpikir secara sistematis, logis dan kritis atau mengembangkan kemampuan intelektual sebagai bagian dari proses mental.

$$
\text { Selanjutnya Sanjaya }
$$

menjelaskan strategi pembelajaran inkuiri akan efektif manakala: (1) guru mengharapkan siswa dapat menemukan sendiri jawaban dari suatu permasalahan yang ingin dipecahkan, (2) jika bahan pelajaran yang akan diajarkan tidak berbentuk fakta atau konsep yang sudah jadi, akan tetapi sebuah kesimpulan yang perlu pembuktian, (3) jika proses pembelajaran berangkat dari rasa ingin tahu siswa terhadap sesuatu, (4) jika guru akan mengajar pada sekelompok siswa yang rata-rata memiliki kemauan dan dan kemampuan berpikir. Strategi pembelajaran inkuiri akan kurang berhasil diterapkan kepada siswa yang kurang memiliki kemampuan untuk berpikir, (5) jika jumlah siswa yang belajar tidak terlalu banyak sehingga bisa dikendalikan oleh guru, dan (6) jika guru memiliki waktu yang cukup untuk menggunakan pendekatan yang berpusat pada siswa.

Joyce, Weil dan Calhoun (2009) menjelaskan sintaks pembelajaran inkuiri terdiri dari 5 tahap utama yaitu: (1) tahap pertama menghadapkan pada masalah, dalam hal ini menjelaskan prosedur-prosedur dan menjelaskan perbedaan-perbedaan, (2) tahap kedua pengumpulan data untuk verifikasi, dalam hal ini memverifikasi hakikat objek dan kondisinya, memverifikasi peristiwa dari keadaan permasalahan, (3) tahap ketiga pengumpulan data untuk eksperimen, dalam hal ini memisahkan variabel yang relevan, menghipotesiskan serta menguji hubungan kausal, (4) tahap keempat merumuskan penjelasan, dalam hal ini memformulasikan aturan dan penjelasan, dan (5) tahap menganalisis inkuari, dalam hal ini menganalisis strategi dan mengembangkan yang paling efektif.

Hal senada berkaitan dengan sintaks pembelajaran inkuiri dipaparkan Jacobsen, Eggen dan Kauchak (2009) menjelaskan sintaks pembelajaran inkuiri yaitu: mengidentifikasi masalah, (2) membentuk hipotesis, (3) mengumpulkan data, (4) menganalisis data dan membuat kesimpulan. Selanjutnya dijelaskan bahwa dampak pembelajaran langsung dari strategi pembelajaran inkuiri adalah mengembangkan 
keterampilan proses sains siswa dan meningkatkan kemampuan untuk melakukan penyelidikan secara kreatif. Kemudian sebagai efek pengiring dari strategi pembelajaran inkuiri adalah meningkatkan semangat berkreativitas siswa, kebebasan dalam belajar, menghargai pendapat orang lain.

Trianto (2009) menjelaskan sintaks pembelajaran inkuiri yaitu: (1) menyajikan pertanyaan atau masalah, dalam hal ini guru membimbing siswa mengidentifikasi masalah, (2) membuat hipotesis, dalam hal ini guru memberikan kesempatan pada siswa untuk berdiskusi untuk membuat hipotesis. Guru membimbing siswa dalam menentukan hipotesis yang relevan dengan permasalahan dan memprioritaskan masalah mana yang menjadi prioritas penyelidikan, (3) merancang percobaan, dalam hal ini guru memberikan kesempatan kepada siswa untuk menentukan langkah-langkah yang sesuai dengan hiptesis yang akan dilakukan. Guru membimbing siswa mengurutkan langkah-langkah percobaan, (4) melakukan percobaan untuk memperoleh informasi, dalam hal ini guru membimbing siswa mendapatkan informasi melalui percobaan, (5) mengumpulkan dan menganalisis data, dalam hal ini guru memberi kesempatan pada tiap kelompok untuk menyampaikan hasil pengolahan data yang terkumpul, dan (6) membuat kesimpulan, dalam hal ini siswa bersama guru membuat kesimpulan.

Advanced organizer adalah bahan pengantar pelajaran yang disajikan di kelas. Bahan pengantar ini disajikan dalam bentuk abstraksi (singkatan) dan saling terkait di antara bahan itu sendiri (Joyce, Weil dan Calhoun, 2009). Tujuan advanced organizer adalah untuk membantu guru menyampaikan sejumlah bahan informasi secara bermakna dan seefisien mungkin. Di samping itu penggunaan pengorganisasian awal juga bertujuan memperkuat struktur kognitif siswa, sehingga mampu menghubungkan informasi baru dengan ide-ide relevan yang telah ada dalam struktur kognitifnya. Memperkuat struktur kognitif adalah meningkatkan kemampuan siswa mengorganisasikan bahan pelajaran baru dengan baik, jelas dan stabil. Dengan demikian pengorganisasian awal dapat meningkatkan retensi dan pemahaman baru terhadap bahan pelajaran yang baru dipelajarinya.

Gredler (1991) menjelaskan maksud yang dapat dicapai dengan penerapan advanced organizer dalam pembelajaran yaitu: (1) advanced organizer memberikan kerangka konseptual untuk proses belajar yang bakal terjadi berikutnya, (2) dengan advanced organizer yang dibuat secara seksama dapat terjadi hubungan antara informasi yang sudah tersimpan di dalam struktur kognitif siswa dengan bahan ajar yang baru, dan (3) karena advanced organizer berfungsi sebagai jembatan antara yang lama dengan struktur kognitif yang akan diperoleh sehingga advanced organizer memperlancar proses pemberian kode informaai tersebut pada siswa.

Proses pengaitan/penghubung informasi baru dengan konsep relevan yang sudah ada dalam struktur kognitif siswa, merupakan kegiatan pemrosesan informasi yang terjadi dalam memori jangka panjang. Dengan demikian, pengorganisasian awal merupakan alat bantu untuk terjadinya pemrosesan informasi yang diterima manusia. Jadi, pada hakekatnya pengorganisasian awal merupakan alat yang perlu untuk mempersiapkan siswa dalam belajar agar dapat melakukan pemrosesan informasi dengan baik, sehingga terjadi pengaitan informasi baru dengan ide-ide relevan yang telah ada dalam struktur kognitif siswa. Hergenhahn dan Olson (2008) menjelaskan hukum kesiapan (law of readiness), yang dikemukakan oleh Thorndike dalam teori koneksionismenya. Hukum ini menjelaskan kesiapan individu untuk melakukan sesuatu, yaitu bahwa belajar itu lebih berhasil apabila dilandasi oleh kesiapan untuk belajar

Hergenhahn dan Olson (2008) menjelaskan belajar dapat diklasifikasikan ke dalam dua dimensi yaitu: (1) berhubungan dengan cara informasi atau materi pelajaran disampaikan pada siswa melalui informasi atau penemuan, dan (2) menyangkut bagaimana siswa dapat mengaitkan informasi itu pada struktur kognitif yang telah ada. Pada tingkat pertama dalam belajar, informasi dapat dikomunikasikan pada siswa, baik dalam bentuk belajar penerimaan yang menyajikan informasi itu dalam bentuk final, maupun dalam bentuk belajar penemuan yang mengharuskan siswa menemukan sendiri sebahagian atau seluruh materi yang akan diajarkan. Pada tingkat kedua, siswa menghubungkan atau mengaitkan informasi itu pada pengetahuan yang telah dimilikinya, dalam hal ini terjadi belajar bermakna. Akan tetapi, siswa itu dapat juga hanya menghafalkan informasi baru itu, 
tanpa menghubungkannya pada konsep-konsep yang telah ada dalam struktur kognitifnya.

Konsep belajar bermakna merupakan suatu proses mengaitkan informasi baru kepada konsep-konsep relevan yang terdapat dalam struktur kognitif seseorang. Walaupun tidak mengetahui mekanisme biologi tentang memori atau disimpannya pengetahuan, kita mengetahui bahwa informasi disimpan didaerah-daerah tertentu dalam otak. Banyak sel otak yang terlibat dalam penyimpanan pengetahuan itu. Dengan berlangsungnya belajar, dihasilkan perubahan-perubahan dalam sel otak, terutama sel-sel yang menyimpan informasi yang mirip dengan informasi yang sedang dipelajari (Hergenhahn dan Olson, 2008).

West, dkk dalam Hamid (2007) menjelaskan beberapa ciri advanced organizer yaitu: (1) berupa abstraksi, (2) sebuah jembatan yang menghubungkan informasi baru dengan pengetahuan yang telah dimiliki siswa, (3) suatu pengantar dari materi baru, unit atau pelajaran, (4) berupa suatu garis besar abstrak dari informasi baru dan berupa suatu pernyataan kembali dari pengetahuan awal, memberikan siswa suatu struktur informasi baru, (6) mendorong siswa untuk mentransfer atau mengaplikasikan apa yang diketahuinya dan (7) berisikan muata yang memiliki subtansi intelektual yang cukup tidak sekedar pengetahuan umum biasa.

Selanjutnya Meyer dalam Hamid (2007) menjelaskan ciri ciri advanced organizer apabila dapat menampilkan: (1) seperangkat informasi singkat verbal atau visual, (2) disajikan sebelum mempelajari seluruh informasi dari materi yang akan dipelajari, (3) tidak memuat isi pelajaran secara khusus dari materi atau informasi yang akan dipelajari, (4) memberikan suatu makna yang logis di antara hubungan komponen-komponen yang akan dipelajari, dan (5) mempengaruhi proses pengkodean oleh siswa.

Prosedur untuk menyusun advanced organizer dijelaskan West dkk dalam Hamid (2007) sebagai berikut: (1) kenali pelajaran baru atau unit untuk menemukan pengetahuan prasyarat, (2) diajarkan kembali bila perlu, (3) kenali apakah siswa telah mengetahui bahan/materi pelajaran, (4) buatlah daftar atau rangkuman tentang prinsip-prinsip atau ide-ide umum yang utama pada pelajaran atau pokok bahasan yang baru (dapat dilakukan pertama kali), (5) tulislah satu paragrap yang menekankan prinsip-prinsip umum yang utama, persamaan, topik-topik baru dengan yang lama, dan (6) subtopik utama dari unit atau pelajaran harus meliputi urutan yang sama seperti disajikan dalam advance organizer.

De Bono (1981) menjelaskan pada prinsipnya berpikir adalah untuk memungkinkan suatu organisme yang hidup untuk bertahan dengan mendapatkan sesuatu yang dibutuhkan dan menghindari sesuatu yang berbahaya. Kemudian ia juga mengatakan berfikir sebagai eksplorasi pengalaman yang dalam praktek sehari-hari seringkali sulit untuk diterima. Suryabrata (2001) menyatakan bahwa berfikir adalah meletakkan bagian pengetahuan yang diperoleh manusia. Pengetahuan yang di maksudnya mencakup konsep, gagasan dan pengertian yang telah dimiliki atau di perinci manusia.

Santrock (2008) menjelaskan berpikir adalah memanipulasi atau mengelola dan mentransformasi informasi dalam memori. Dengan demikian berpikir adalah sarana individu untuk mengapresiasikan, mengekplorasikan dan merubah isi dunia serta merencanakan tindakan yang dapat berubah dunia luar. Sarwono (1997) menyatakan berpikir adalah suatu proses merencanakan, mengingat dan mengeluarkan sesuatu yang dipahami sesuai dengan keadaan yang diperlukan. Dalam perkembangannya kemampuan berpikir manusia terus berkembang. Hasil pemikiran manusia tersebut melahirkan filsafat dan ilmu.

Suriasumantri (2001) menjelaskan berpikir merupakan kegiatan untuk menemukan pengetahuan yang benar dan untuk menemukan pengetahuan yang benar itu menggunakan proses berfikir dalam menarik suatu kesimpulan yang berupa pengetahuan. Sedangkan De Bono (1981) menjelaskan tujuan dasar berpikir secara biologis adalah untuk mempertahankan hidup suatu organisme dengan mendapatkan sesuatu yang dibutuhkan dan menjauhi semua yang berbahaya. Dengan demikian berpikir adalah sarana individu untuk mengapresiasikan, mengekplorasikan dan merubah isi dunia serta merencanakan tindakan yang dapat berubah dunia luar.

Eysenck dan Maili (1972) menyatakan bahwa kemampuan berpikir logis adalah kemampuan seseorang menarik kesimpulan dari premis-premis sebelumnya. Suryasumantri (2000) menegaskan ketepatan penarikan kesimpulan bergantung dari tiga hal yaitu (1) kebenaran premis mayor, (2) kebenaran premis 
minor, (3) keabsahan pengambilan kesimpualan. Debono (1981) menyatakan inti sari dari proses berpikir logis adalah, benar pada setiap langkah pada gilirannya mengarah pada penarikan kesimpulan yang benar.

Piaget dalam Ardhana

menyatakan bahwa kemampuan berpikir logis mempunyai beberapa pengertian, antara lain: skema, assimilasi, akomodasi dan ekulibrium. Skema adalah struktur kognitif yang merupakan kemampuan berpikir individu untuk mengorganisasi lingkungannya. Secara sederhana skema dapat juga diartikan sebagai konsep yang dapat digunakan untuk mengidentifikasikan jenis-jenis rangsangan yang datang dari luar. Dengan demikian, seseorang siswa jika telah memiliki kemapuan untuk mengidentifikasi jenis-jenis rangsangan yang datang dari luar, maka dia akan lebih mampu untuk mempelajari dan memikirkan cara-cara atau prosedur penyelesaian masalah atau soal-soal yang dihadapinya secara sistematis.

Menurut Sutherland dan Piaget dalan De Bono (1981) ada empat tingkatan perkembangan berpikir logis yaitu: tingkat sensor (sensorimotor), tingkat pra operasi (preoperation), tingkat operasi konkrit (concrete operation) dan tingkat operasi formal (formal operation). Tingkat kemampuan berpikir logis yang tertinggi adalah tingkat operasi formal, dimana usia siswa berada pada usia 11-15 tahun. Pada usia ini, siswa telah memiliki kemampuan dan dapat melakukan logika induktif dan deduktif di dalam memecahkan masalah belajar.

Penelitian Bahri (2007) tentang Pengaruh Pembelajaran Inkuiri dan Tingkat Pengetahuan Peta Terhadap Hasil Belajar Geografi Siswa SMP Swasta PAB 3 Saentis Percut Sei Tuan Kabupaten Deli Serdang, menemukan bahwa siswa yang diajar dengan pembelajaran inkuiri memperoleh hasil belajar Geografi lebih tinggi dibandingkan dengan siswa yang diajar dengan strategi konvensional. Demikian pula siswa dengan tingkat pengetahuan peta tinggi memperoleh hasil belajar Geografi yang lebih tinggi dibandingkan siswa dengan tingkat pengetahuan peta rendah.

Penelitian Willy (2010) tentang Pengaruh Strategi Pembelajaran Dan Gaya Kognitif Terhadap Pemahaman Bacaan Bahasa Inggris Di SMPS Ahmad Yani Binjai menyimpulkan keseluruhan rata-rata pemahaman bacaan bahasa Inggris yang diajar dengan strategi pembelajaran advanced organizer lebih tinggi daripada rata-rata pemahaman bacaan siswa yang diajar dengan strategi pembelajaran ekspositori. Hal ini menunjukkan bahwa strategi pembelajaran advanced organizer terbukti efektif dapat meningkatkan pemahaman bacaan bahasa Inggris siswa secara keseluruhan baik untuk kelompok siswa dengan gaya kognitif field independent maupun kelompok siswa dengan gaya kognitif field dependent.

Penelitian dari Pangaribuan (2007) tentang Pengaruh Pendekatan Pembelajaran Dan Kemampuan Berpikir Logis Terhadap Hasil Belajar biologi Siswa SMA Negeri 1 Binjai, menemukan bahwa nilai rata-rata hasil belajar siswa dengan kemampuan berpikir logis tinggi secara keseluruhan baik yang dibelajarkan dengan pendekatan keterampilan proses terbimbing maupun konvensional lebih tinggi dibandingkan dengan rata-rata hasil belajar siswa dengan kemampuan berpikir logis rendah.

Permasalahan penelitian sebagai berikut: (1) Apakah hasil belajar biologi siswa MAN Kota Medan yang diajar dengan strategi pembelajaran inkuiri lebih tinggi daripada hasil belajar biologi yang diajar dengan strategi pembelajaran advanced organizer ?; (2) Apakah hasil belajar biologi siswa MAN Kota Medan yang memiliki kemampuan berpikir logis tinggi lebih tinggi daripada hasil belajar biologi siswa dengan kemampuan berpikir logis rendah?, dan (3) Apakah terdapat interaksi antara strategi pembelajaran dan kemampuan berpikir logis siswa dalam mempengaruhi hasil belajar biologi siswa MAN Kota Medan?

\section{METODE}

Penelitian dilakukan di madrasah aliyah negeri (MAN) Kota Medan yaitu MAN 1 Medan dan MAN 2 Medan. Populasi dalam penelitian ini adalah seluruh siswa kelas XI IPA terdiri yang tersebar dalam 4 kelas dan kelas XI IPA dalam 5 kelas. Teknik pengambilan sampel dalam penelitian ini dilakukan melalui pengambilan sampel secara cluster random sampling. Untuk menetapkan jumlah sampel ada dua persyaratan penting yang harus dipenuhi. Sampel penelitian dipilih secara acak dengan mengundi 4 kelas di MAN 1 untuk mendapatkan 2 kelas sebagai sampel penelitian. Dari hasil pengundian, terpilih dua kelas sebagai kelas yang diajar dengan strategi pembelajaran inkuiri yaitu kelas XI IPA 4 dan 
XI IPA 3 berjumlah 50 siswa sedangkan untuk kelas yang diajar dengan strategi pembelajaran advanced organizer diundi dari dari 5 kelas di MAN 2 yaitu terpilih kelas XI IPA 3 dan Kelas XI IPA 5 berjumlah 50 siswa. Sebelum diberikan perlakuan, terlebih dahulu diberikan tes kemampaun berpikir logis, untuk membedakan siswa yang memiliki kemampuan berpikir logis tinggi dan siswa yang memiliki kemampuan berpikir logis rendah.

Penelitian ini menggunakan metode quasi eksperimen dengan desain faktorial $2 \times 2$. Melalui desain ini dibandingkan pengaruh perlakuan pembelajaran dengan menggunakan strategi pembelajaran inkuiri dan strategi pembelajaran advanced organizer ditinjau dari kemampuan berpikir logis siswa.

Tabel 1. Rancangan Ekperimen Desain Faktorial 2 x 2

\begin{tabular}{|c|c|c|}
\hline$\overbrace{\text { Kemampuan Berpikir Logis (B) }}^{\text {Strategi Pembelajaran (A) }}$ & Inkuiri $\left(A_{1}\right)$ & Advanced Organizer $\left(\mathrm{A}_{2}\right)$ \\
\hline Tinggi $\left(\mathrm{B}_{1}\right)$ & $A_{1} B_{1}$ & $\mathrm{~A}_{2} \mathrm{~B}_{1}$ \\
\hline Rendah $\left(\mathrm{B}_{2}\right)$ & $\mathrm{A}_{1} \mathrm{~B}_{2}$ & $\mathrm{~A}_{2} \mathrm{~B}_{2}$ \\
\hline
\end{tabular}

Keterangan:

$\mathrm{A}_{1} \mathrm{~B}_{1}$ : Hasil belajar biologi siswa yang diajar dengan strategi pembelajaran inkuiri pada siswa dengan kemampuan berpikir logis tinggi

$A_{1} B_{2}$ : Hasil belajar biologi siswa yang diajar dengan strategi pembelajaran inkuiri pada siswa dengan kemampuan berpikir logis rendah

$A_{2} B_{1}$ : Hasil belajar biologi siswa yang diajar dengan strategi pembelajaran advanced organizer pada siswa dengan kemampuan berpikir logis tinggi

$A_{2} B_{2}$ : Hasil belajar biologi siswa yang diajar dengan strategi pembelajaran advanced organizer pada siswa dengan kemampuan berpikir logis personal rendah

Teknik analis data yang digunakan adalah teknik statistik deskriptif dan inferensial. Teknik statistik deskriptif digunakan untuk mendeskripsikan data, antara lain: nilai ratarata, median, simpangan baku dan kecenderungan data. Teknik statistik inferensial digunakan untuk menguji hipotesis penelitian yaitu analisis varians dua jalur dengan taraf signifikan $\alpha=0,05$. Sebelumnya terlebih dahulu diuji persyaratan analisis yakni persyaratan uji normalitas dan homogenitas. Kriteria pengujian hipotesis adalah terima Ho jika $F_{\text {hitung }}<\mathrm{F}_{\text {tabel }}$ pada taraf signifikansi $\alpha=0,05$ dengan $\mathrm{dk}=$ $(\mathrm{k}, \mathrm{n}-\mathrm{k})$, dan untuk harga yang lainnya tolak Ho. Kemudian dilakukan uji lanjut dengan menggunakan uji Tukey, karena anggota kelompok sampel berjumlah sama.

Adapun hipotesis statistik yang akan diuji adalah:

1. Ho : $\mu_{\mathrm{A} 1}=\mu_{\mathrm{A} 2}$

$\mathrm{Ha}: \mu_{\mathrm{A} 1}>\mu_{\mathrm{A} 2}$

2. Ho : $\mu_{\mathrm{B} 1}=\mu_{\mathrm{B} 2}$

$\mathrm{Ha}: \mu_{\mathrm{B} 1}>\mu_{\mathrm{B} 2}$

3. Ho : $\mathrm{A}><\mathrm{B}=0$

$\mathrm{Ha}: \mathrm{A}><\mathrm{B} \neq 0$

\section{HASIL DAN PEMBAHASAN \\ Hasil}

Deskripsi data yang disajikan dalam penelitian terdiri dari skor hasil belajar Biologi yang diajar dengan menggunakan strategi pembelajaran inkuiri dan advanced organizer, demikian juga hasil belajar Biologi siswa yang dikelompokkan atas kemampuan berpikir logis tinggi dan kemampuan berpikir logis rendah. Rangkuman data hasil belajar Biologi siswa dapat dilihat pada Tabel 2 .

Tabel 2. Rangkuman Data Hasil Belajar Biologi Siswa 
Jurnal Teknologi Pendidikan, Vol. 8 No. 2 Oktober 2015, p-ISSN; 1979-6692, e-ISSN: 2407-7437

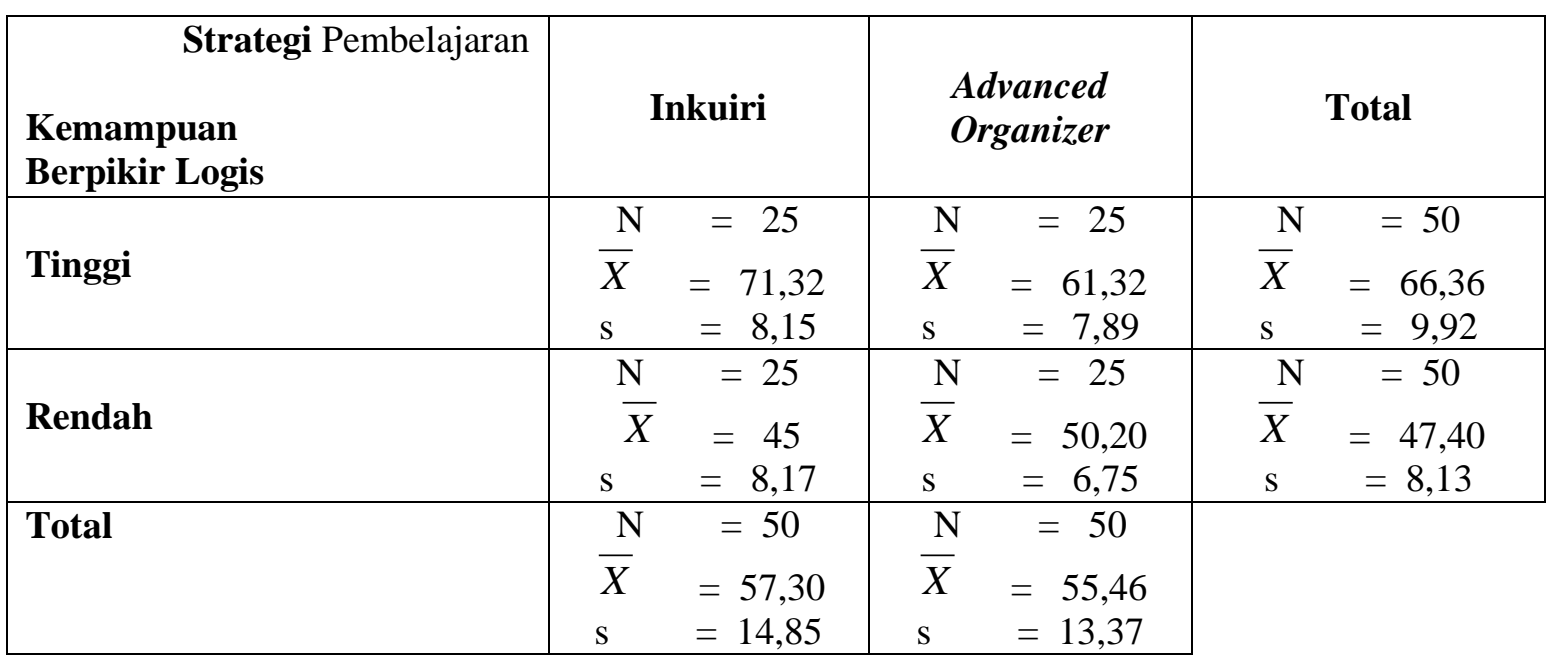

Pengujian hipotesis penelitian dilakukan dengan menggunakan ANAVA dua jalur kemudian dilakukan uji lanjut dengan menggunakan uji Tukey. Berdasarkan data di atas maka selanjutnya dilakukan pengujian hipotesis. Rangkuman hasil perhitungannya dapat dilihat pada Tabel 3 berikut ini:

Tabel 3. Rangkuman Perhitungan Anava Faktorial 2 x 2

\begin{tabular}{|l|l|l|l|l|l|l|}
\hline \multirow{2}{*}{ Sumber Variasi } & \multirow{2}{*}{$\mathbf{d k}$} & \multirow{2}{*}{ Jk } & \multirow{2}{*}{ Rjk } & \multirow{2}{*}{ F hitung } & Ftabel $_{(\mathbf{1}, \mathbf{9 6})}$ \\
\cline { 6 - 8 } & & & $(\mathbf{p = 0 , 0 5 )}$ & $\mathbf{( p = 0 , 0 1 )}$ \\
\hline Strategi pembelajaran & 1 & 484,64 & 484,64 & 11,53 & 3,944 & 6,903 \\
Berpikir Logis & 1 & 9660,04 & 9660,04 & 229,94 & 3,994 & 6,903 \\
Interaksi & 1 & 1532,16 & 1532,16 & 36,47 & 3,994 & 6,903 \\
Galat & 96 & 4033,72 & 42,01 & & & \\
\hline Total & 99 & 15710,56 & - & - & - & \\
\hline
\end{tabular}

\section{Rata-Rata Hasil Belajar}

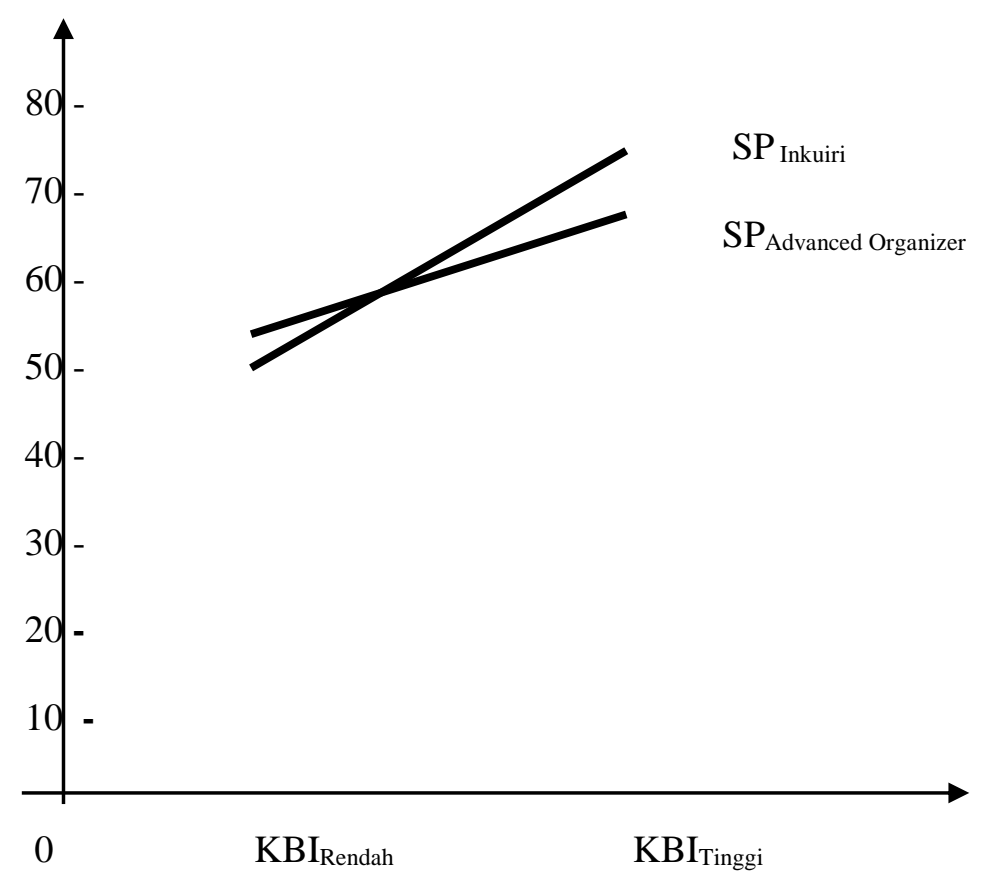

Gambar 1. Interaksi Strategi Pembelajaran Dan Kemampuan berpikir logis 
Dengan terujinya secara signifikan interaksi antara strategi pembelajaran dan kemampuan berpikir logis terhadap hasil belajar Biologi, maka dilakukan uji lanjut. Sehubungan dengan jumlah sampel (n) pada setiap kelompok sama, maka dilakukan uji lanjut dengan menggunakan uji Tukey. Hasil perhitungan uji lanjut untuk setiap kelompok yang dibandingkan disajikan pada Tabel 4.

Tabel 4. Rangkuman Uji Lanjut

\begin{tabular}{|l|l|l|l|l|}
\hline \multicolumn{2}{|l|}{ Hipotesis Statistik } & $\mathrm{F}_{\text {-hitung }}$ & $\mathrm{F}_{\text {-tabel }(3,96)}(\alpha=0,05)$ & Keterangan \\
\hline $\mathrm{H}_{\mathrm{O}: \mu 11=\mu 12}$ & $\mathrm{Ha}: \mu 11>\mu 12$ & 5,46 & 2,704 & Signifikan \\
\hline $\mathrm{H}_{\mathrm{O}: \mu 11=\mu 21}$ & $\mathrm{Ha}: \mu 11>\mu 21$ & 14,38 & 2,704 & Signifikan \\
\hline $\mathrm{H}_{\mathrm{O}: \mu 11=\mu 22}$ & $\mathrm{Ha}: \mu 11>\mu 22$ & 11,54 & 2,704 & Signifikan \\
\hline $\mathrm{H}_{\mathrm{O}: \mu 12=\mu 21}$ & $\mathrm{Ha}: \mu 12>\mu 21$ & 8,91 & 2,704 & Signifikan \\
\hline $\mathrm{H}_{\mathrm{O}: \mu 12=\mu 22}$ & $\mathrm{Ha}: \mu 12>\mu 22$ & 6,07 & 2,704 & Signifikan \\
\hline
\end{tabular}

\section{Pembahasan}

Pada paparan sebelumnya diketahui secara keseluruhan rata-rata hasil belajar Biologi siswa yang diajar dengan strategi pembelajaran inkuiri lebih tinggi daripada ratarata hasil belajar Biologi siswa yang diajar dengan strategi pembelajaran advanced organizer. Hal ini menunjukkan bahwa strategi pembelajaran inkuiri terbukti efektif dapat meningkatkan hasil belajar siswa secara keseluruhan baik untuk kelompok kemampuan berpikir logis tinggi maupun kemampuan berpikir logis rendah. Dari hasil temuan ini menunjukkan bahwa untuk mengajarkan materi ajar Biologi lebih baik menggunakan strategi pembelajaran inkuiri daripada dengan strategi pembelajaran advanced organizer. Hal ini sejalan dengan ungkapan Sanjaya (2007) bahwa strategi pembelajaran merupakan rangkaian kegiatan pembelajaran yang menekankan pada proses berpikir secara kritis dan analitis untuk mencari dan menemukan sendiri jawaban dari suatu masalah yang dipertanyakan. Temuan penelitian, mendukung penelitian Bahri (2007) tentang Pengaruh Pembelajaran Inkuiri dan Tingkat Pengetahuan Peta Terhadap Hasil Belajar Geografi Siswa SMP Swasta PAB 3 Saentis Percut Sei Tuan Kabupaten Deli Serdang, menemukan bahwa siswa yang diajar dengan pembelajaran inkuiri memperoleh hasil belajar Geografi lebih tinggi dibandingkan dengan siswa yang diajar dengan strategi konvensional. Demikian pula siswa dengan tingkat pengetahuan peta tinggi memperoleh hasil belajar yang lebih tinggi dibandingkan siswa dengan pengetahuan peta rendah.

Jika diperhatikan lebih lanjut bahwa pada pembelajaran strategi pembelajaran inkuiri rata-rata hasil belajar Biologi siswa dengan kemampuan berpikir logis tinggi lebih tinggi daripada hasil belajar Biologi siswa dengan kemampuan berpikir logis rendah. Sedangkan pada strategi pembelajaran advanced organizer, rata-rata hasil belajar Biologi siswa dengan kemampuan berpikir logis tinggi lebih tinggi daripada hasil belajar Biologi siswa dengan kemampuan berpikir logis rendah. Hal ini menunjukkan bahwa kemampuan berpikir logis belajar signifikan untuk membedakan hasil belajar Biologi siswa, di mana siswa dengan kemampuan berpikir logis tinggi lebih baik yang diajar dengan strategi pembelajaran inkuiri, sedangkan untuk untuk siswa dengan kemampuan berpikir logis rendah lebih baik diajar dengan strategi advanced organizer.

Hasil penelitian menunjukkan semua hipotesis penelitian yaitu peneliti ajukan dapatlah diterima. Hipotesis pertama yang menyatakan hasil belajar Biologi siswa yang diajar dengan strategi pembelajaran inkuiri lebih tinggi daripada hasil belajar Biologi siswa yang diajar dengan strategi pembelajaran advanced organizer. Hal ini dapat dimaklumi karena melalui strategi pembelajaran inkuiri dapat mendorong siswa untuk aktif belajar karena siswa dapat mencari informasi-informasi yang beragam dan beraneka sumber. Di samping itu strategi pembelajaran inkuiri bertujuan menumbuhkan partisipasi siswa dalam memecahkan isu atau masalah yang diajukan tenaga pengajar dalam pembelajaran, menumbuhkan diskusi di antara siswa dalam mencari penyebab dan solusi terhadap isu atau masalah tersebut. Oleh karena itu peran tenaga pengajar dalam pembelajaran inkuiri sebagai fasilitator yang mengarahkan siswa untuk mengkonstruk sendiri pengetahuannya. 
Pengujian hipotesis kedua menunjukkan bahwa hasil belajar Biologi siswa dengan kemampuan berpikir logis tinggi lebih tinggi dari pada siswa dengan kemampuan berpikir logis rendah. Hasil ini membuktikan bahwa kemampuan berpikir logis dalam belajar signifikan untuk membedakan hasil belajar Biologi. Kemampuan berpikir logis dalam penelitian ini dikategorikan atas dua kategori yaitu tinggi dan rendah. Dari hasil analisis data secara keseluruhan diperoleh rata-rata hasil belajar Biologi siswa dengan kemampuan berpikir logis tinggi lebih tinggi daripada hasil belajar Biologi siswa dengan kemampuan berpikir logis rendah. Dengan demikian siswa dengan kemampuan berpikir logis tinggi lebih memahami dan menguasai materi ajar Biologi dibandingkan siswa dengan kemampuan berpikir logis rendah. Hal ini sejalan dengan hasil penelitian Pangaribuan (2007) tentang Pengaruh Pendekatan Pembelajaran Dan Kemampuan Berpikir Logis Terhadap Hasil Belajar biologi Siswa SMA Negeri 1 Binjai. Hasil penelitian yang diperoleh dari nilai ratarata hasil belajar siswa dengan kemampuan berpikir logis tinggi secara keseluruhan baik yang diajar dengan pendekatan keterampilan proses terbimbing maupun konvensional lebih tinggi dibandingkan dengan rata-rata hasil belajar siswa dengan kemampuan berpikir logis rendah.

Strategi pembelajaran inkuiri lebih efektif untuk meningkatkan hasil belajar Biologi pada siswa dengan karakteristik kemampuan berpikir tinggi dibandingkan siswa dengan kemampuan berpikir logis rendah sebab siswa yang memiliki kemampuan berpikir logis tinggi adalah siswa yang selalu menggunakan potensi berpikir yang ada pada dirinya dalam memecahkan persoalan-persoalan dalam kegiatan belajar. Kemampuan berpikir logis siswa yang tinggi ditandai dengan kemampuan untuk mencari jawaban atas masalah atau isu yang dikemukakan, menciptakan sesuatu yang baru, bernalar dan berinisiatif dengan melihat hubungan antara berbagai unsur yang terlibat secara langsung maupun tidak langsung dalam memecahkan berbagai masalah yang dihadapi

Strategi pembelajaran inkuiri lebih tinggi dari siswa dengan kemampuan berpikir logis rendah yang diajar dengan menggunakan strategi pembelajaran advanced organizer. Hal ini disebabkan siswa yang memiliki kemampuan berpikir logis tinggi cenderung mencoba menyelesaikan tugas yang diberikan dengan kemampuan yang dimilikinya untuk mempelajari materi ajar yang terdapat di dalam buku Biologi. Rata-rata hasil belajar Biologi siswa dengan kemampuan berpikir logis tinggi yang diajar dengan menggunakan strategi pembelajaran advanced organizer lebih tinggi dari siswa dengan kemampuan berpikir logis rendah yang diajar dengan menggunakan strategi pembelajaran inkuiri. Hal ini menunjukkan bahwa pada siswa dengan kemampuan berpikir logis tinggi lebih efektif diajar dengan strategi advanced organizer daripada strategi pembelajaran inkuiri dan karakteristik siswa kemampuan berpikir logis rendah. Hal ini terjadi karena kecenderungan lain yang dimiliki oleh siswa yang memiliki kemampuan berpikir logis tinggi adalah bahwa mereka dengan sungguh-sungguh walaupun diajar dengan strategi pembelajaran advanced organizer.

Strategi pembelajaran advanced organizer lebih tinggi dari siswa dengan kemampuan berpikir logis rendah yang diajar dengan strategi pembelajaran advanced organizer. Hal ini bermakna bahwa penerapan strategi pembelajaran advanced organizer efektif untuk meningkatkan hasil belajar Biologi siswa pada siswa dengan kemampuan berpikir logis tinggi daripada siswa dengan kemampuan berpikir logis rendah. Rata-rata hasil belajar Biologi siswa dengan kemampuan berpikir logis rendah yang diajar dengan menggunakan strategi pembelajaran inkuiri lebih rendah dari siswa dengan kemampuan berpikir logis rendah yang diajar dengan menggunakan strategi pembelajaran advanced organizer. Hal ini bermakna bahwa pada siswa dengan kemampuan berpikir logis rendah, maka strategi yang tepat dalam kegiatan pembelajaran adalah strategi pembelajaran advanced organizer.

\section{PENUTUP \\ Simpulan}

Pertama, rata-rata hasil belajar Biologi siswa yang diajar dengan strategi pembelajaran inkuiri lebih tinggi dibandingkan dengan rata- 
rata hasil belajar siswa yang diajar dengan strategi pembelajaran advanced organizer. Dengan demikian strategi pembelajaran inkuiri lebih efektif diterapkan dalam pembelajaran Biologi.

Kedua, rata-rata hasil belajar Biologi siswa dengan kecenderungan tingkat kemampuan berpikir logis tinggi secara keseluruhan baik yang diajar dengan strategi pembelajaran inkuiri dan strategi pembelajaran advanced organizer lebih tinggi dibandingkan dengan rata-rata hasil belajar Biologi siswa dengan kecenderungan tingkat kemampuan berpikir logis rendah.

Ketiga, perbedaan pengaruh strategi pembelajaran dan kemampuan berpikir logis adalah siswa dengan kemampuan berpikir logis tinggi lebih tepat diajar dengan strategi pembelajaran inkuiri daripada diajar dengan strategi pembelajaran advanced organizer, sedangkan siswa dengan kemampuan berpikir logis rendah lebih tepat diajar dengan strategi pembelajaran advanced organizer daripada diajar dengan strategi pembelajaran inkuiri.

\section{Saran}

1. Kepada pihak tenaga pengajar perlu melihat karakteristik kemampuan berpikir logis siswa di dalam menerapkan strategi pembelajaran inkuiri dan advanced organizer. Untuk siswa dengan kemampuan berpikir logis tinggi lebih tepat diajar dengan strategi pembelajaran inkuiri sedangkan bagi siswa dengan kemampuan berpikir logis rendah maka strategi pembelajaran yang lebih tepat diterapkan adalah strategi pembelajaran advanced organizer.

2. Kepada pihak pengelola MAN Kota Medan agar memotivasi guru-guru dalam kegiatan pembelajaran Biologi untuk menerapkan strategi pembelajaran inkuiri karena melalui penelitian ini terbukti bahwa pembelajaran inkuiri dapat meningkatkan hasil belajar.

3. Kepada pihak Mapenda Kementerian Agama untuk memfasilitas kegiatan peningkatan mutu guru melalui berbagai kegiatan pelatihan sehingga guru-guru MAN memiliki kompetensi profesional dalam melaksanakan pembelajaran.
4. Kepada peneliti lain yang ingin meneliti lebih lanjut tentang strategi pembelajaran inkuiri hendaknya memperhatikan variabel-variabel lainnya khususnya yang berkaitan dengan karakteristik siswa sehingga diperoleh pengetahuan yang lebih luas lagi.

\section{DAFTAR PUSTAKA}

Arikunto, S. (2002). Dasar-Dasar Evaluasi Pendidikan Edisi Revisi. Jakarta: Bumi Aksara.

Arend, I.R. (2008). Learning To Teaching. Buku Dua. Penerjemah Helly Prajitno Soetjipto dan Sri Mulyantini Soetjipto, Yogyakarta: Pustaka Pelajar

De Bono, E. (1981). Practical Thinking. London: Penguin Books

Dick, W. dan Carey, L. (1996). The Systematic Design of Instruction. Fouth Edition. New York: Harper Collin College Publisher.

Djuwita, A. (2011). "Perpaduan Aktivitas Intelektual dan Gerakan Fisik Untuk Meningkatkan Hasil Belajar Mengenal Organ Tubuh". Jurnal: Pembelajaran Bermakna IPA. Jakarta: USAID DBE3.

Fauziah, H. (2010). "Pembuatan dan Penerapan Media Animasi Sebagai Upaya Untuk Meningkatkan Kompetensi Mahasiswa Biologi”. Jurnal Tabularasa Vol. 7 No. 1 Juni 2010. Medan: PPs Unimed

Gagne, R. M. (1985). The Condition Of Learning, Third Edition, New York: Holt, Rinehart and Winston.

Gagne, R.M. \& Briggs, L.J. (1979). Principles of Instructional Design. New York: Holt Rinehart and Winston

Gredler, M.E.B. (1994). Learning and Instruction Theory Into Practice, Belajar dan Membelajarkan. Penerjemah: Munandir. Jakarta: Raja Grafindo Persada

Gulo, W. (2008). Strategi Belajar Mengajar. Jakarta: Grasindo.

Hamalik, O. (2004). Proses Belajar Mengajar. Jakarta: Bumi Aksara

Hamid, A.K (2007). Teori Belajar dan Pembelajaran. Medan: PPs Unimed.

Hergenhahn, B.R dan Olson, M.H. (2008). Theories of Learning. Penerjemah: Tri 
Wibowo B.S. Jakarta: Kencana Prenada Media Group.

Jacobsen, D.A., Eggen, $\mathrm{P}$ dan Kauchak, D. (2009). Methods for Teaching, MetodeMetode Pengajaran Untuk Meningkatkan Belajar Siswa TK-SMA Penerjemah: Ahmad Fawaid dan Khoirul Anam. Yogyakarta: Pustaka Pelajar

Joyce, B. Weil, M.dan Calhoun, E. (2009). Models of Teaching, Model-Model Pengajaran. Penerjemah: Achmad Fawaid dan Ateila Mirza, Yogyakarta: Pustaka Pelajar.

Kemp, J.E. (1994). The Instructional Design Process. Proses Perancangan Pengajaran. Penerjemah: Asril Mardjohan. Bandung: ITB.

Manalu, K., dan Sipahutar, H. (2010). "Pengaruh Alat Visualisasi Terhadap Miskonsepsi Siswa Pada Pembelajaran Biologi". Jurnal Pendidikan Biologi Vol 1 No. 3 Edisi Desember 2010. Medan: PPs Unimed

Merril, M.D dan Twitchel D.G. (1994). Instructional Design Theory. New Jersey; Englewood Cliffs

Mulyati. (2005). Psikologi Belajar. Yogyakarta: Andi Ofset.

Poedjiadi, A. (2005). Sains Teknologi Masyarakat: Model Pembelajaran Kontekstual Bermuatan Nilai. Bandung: Remaja Rosdakarya.

Romizowski, A.Z. (1981). Designing Instructional System. New York: Nichol Publishing Company

Sanjaya, W. (2007). Strategi Pembelajaran. Jakarta: Kencana Prenada Media Group.

Santrock, J.W. (2007). Educational Psychology $2^{\text {nd }}$ Edition. Penerjemah: Tri Wibowo B.S. Psikologi Pendidikan. Jakarta: Kencana Predana Media Group

Seels, B.C. and Richey, R.C. (1994). Instructional Technology, The Defenition and Domains of The Field, Washington. Terjemahan. Yusufhadi Miarso.

Sibuea, A.M. dan Amin, M. (2005). “Aspek Psikologi dan Hasil Belajar Siswa SLTP Yang Menggunakan Model Pembelajaran Akselerasi di Kota Medan". Jurnal Penelitian Bidang Pendidikan Volume II
No. 2. Medan: Lembaga Penelitian Unimed

Snelbecker, E.G. 1974. Learning Theory, Instructional Theory and Psychoeducational Design, New York: Mc Graw Hill

Sternberg, R.J. (2008). Cognitive Psychology. Penerjemah: Yudi Santoso. Yogyakarta: Pustaka Pelajar

Sudjana, N. (2002). Dasar-Dasar Proses Belajar Mengajar. Bandung: Sinar Baru Algensindo.

Suparman, A. (2001). Desain Instruksional. Jakarta : PAU- PPAI - UT.

Suriasumantri, J. (2001). Filsafat Ilmu, Sebuah Pengantar Populer. Jakarta: Pustaka Sinar Harapan.

Syah, M. (2004). Psikologi Belajar. Jakarta: Rajagrafindo Persada

Trianto, (2009). Mendesain Model Pembelajaran Inovatif Progesif. Jakarta: Kencana Prenada Media Group

Wena, M. (2009). Strategi Pembelajaran Inovatif Kontemporer Suatu Tinjauan Konseptual Operasional. Jakarta: Bumi Aksara.

Woolfolk. A.E. (2009). Educational Psychology Active Learning Edition. Penerjemah: Helly Prajitno Soetjipto dan Sri Mulyanti Soetjipto. Psikologi Pendidikan. Yogyakarta: Pustaka Pelajar 